\title{
Polyketide synthesis genes associated with toxin production in two species of Gambierdiscus (Dinophyceae)
}

\author{
Gurjeet S. Kohli, ${ }^{1}{ }^{*}$, Uwe John ${ }^{3}$, Rosa I. Figueroa ${ }^{4}$, Lesley L. Rhodes ${ }^{5}$, D. Tim Harwood ${ }^{5}$, Marco Groth ${ }^{6}$, \\ Christopher J. S. Bolch ${ }^{7}$ and Shauna A. Murray ${ }^{1,8}$
}

\begin{abstract}
Background: Marine microbial protists, in particular, dinoflagellates, produce polyketide toxins with ecosystem-wide and human health impacts. Species of Gambierdiscus produce the polyether ladder compounds ciguatoxins and maitotoxins, which can lead to ciguatera fish poisoning, a serious human illness associated with reef fish consumption. Genes associated with the biosynthesis of polyether ladder compounds are yet to be elucidated, however, stable isotope feeding studies of such compounds consistently support their polyketide origin indicating that polyketide synthases are involved in their biosynthesis.
\end{abstract}

Results: Here, we report the toxicity, genome size, gene content and transcriptome of Gambierdiscus australes and G. belizeanus. G. australes produced maitotoxin-1 and maitotoxin-3, while G. belizeanus produced maitotoxin-3, for which cell extracts were toxic to mice by IP injection $\left(L_{50}=3.8 \mathrm{mg} \mathrm{kg}^{-1}\right)$. The gene catalogues comprised 83,353 and 84,870 unique contigs, with genome sizes of $32.5 \pm 3.7 \mathrm{Gbp}$ and $35 \pm 0.88 \mathrm{Gbp}$, respectively, and are amongst the most comprehensive yet reported from a dinoflagellate. We found three hundred and six genes involved in polyketide biosynthesis, including one hundred and ninty-two ketoacyl synthase transcripts, which formed five unique phylogenetic clusters.

Conclusions: Two clusters were unique to these maitotoxin-producing dinoflagellate species, suggesting that they may be associated with maitotoxin biosynthesis. This work represents a significant step forward in our understanding of the genetic basis of polyketide production in dinoflagellates, in particular, species responsible for ciguatera fish poisoning.

\section{Background}

Gambierdiscus species (Dinophyceae) can produce maitotoxins (MTXs), ladder-like polycyclic ether compounds $[1,2]$, a structure principally reported from dinoflagellates. MTX-1 is the largest and the most toxic natural non-biopolymer known $[1,2]$, and is similar to other polyether compounds such as okadaic acid (OA) and brevetoxins (BTXs) produced by Prorocentrum spp and Karenia brevis, respectively (reviewed [3, 4]). A plethora of stable isotope feeding studies conducted on dinoflagellates producing BTXs, OA and dinophysistoxins (DTXs) provide

\footnotetext{
* Correspondence: Gurjeet.kohli@uts.edu.au

${ }^{1}$ Plant Functional Biology and Climate Change Cluster, University of Technology Sydney, Broadway, New South Wales 2007, Australia ${ }^{2}$ School of Biotechnology and Biomolecular Sciences, University of New South Wales, Kensington, New South Wales 2052, Australia

Full list of author information is available at the end of the article
}

substantial evidence to support the polyketide origin of these polyether ladder compounds [3, 5-9]. Despite this, gene clusters associated with the biosynthesis of polyether ladders have not been elucidated, and little is known about the genes involved in this process. Gene clusters responsible for the biosynthesis of the non-ladder polyether compounds, monensin and nanchangmycin, have been elucidated in bacteria $[10,11]$. The putative alkene precursor of these compounds are synthesised via type I polyketide synthases (PKS). It is proposed that the alkene undergoes epoxidation and polyepoxide cyclisation to form ether linkages [12]. In monensin biosynthesis, these steps could be performed by putative epoxidases and epoxide hydrolases, which are also found in the gene cluster responsible for monensin biosynthesis in addition to a full type I PKS assembly $[10,12,13]$. In the case of monensin, the deletion of either of these genes ceases the production of the 
polyether, supporting this hypothesis [12]. In the case of BTXs, it is also proposed that the carbon backbone is mostly trans-polyene, and it undergoes epoxidation and polyepoxide cyclisation to form BTX [7, 14]. Very little evidence has been determined to support this hypothesis for BTXs, however, there is evidence suggesting the presence of beta epoxidation intermediate, shown by ${ }^{18} \mathrm{O}$ incorporation from molecular oxygen into $\mathrm{C}, \mathrm{D}$ and $\mathrm{E}$ rings of $\mathrm{OA}$ [9] and yessotoxins [15]. Similar to the proposed biosynthetic pathway for BTXs [7, 14], we propose a possible biosynthetic pathway for MTX-1 synthesis (Fig. 1), in which the carbon backbone is synthesised via polyketide biosynthesis followed by epoxidation, polyepoxide cyclisation and sulphonation carried out by PKSs, epoxidases, epoxide hydrolases and sulfotransferases.

There are three major functional groups of PKSs. Type I PKS are large multifunctional proteins, comprising several essential domains: acyltransferase domain (AT), $\beta$ ketosynthase domain (KS) and acyl carrier protein (ACP); they can also include $\beta$-ketoacyl reductase (KR), enoyl reductase (ER), methyl transferases (MT), thioesterases (TE) and dehydrogenase (DH) domains [16]. In iterative type I polyketide synthesis the same set of catalytic domains are present in one protein and used in a cyclic fashion for chain elongation, analogous to fatty acid synthesis (FAS) [17, 18]. In contrast, modular type I PKS catalytic domains are organised in modules comprising all required domains for each step and each module is only used once during polyketide assembly [16]. Type II PKS consist of mono-functional proteins with each catalytic domain on a separate peptide that form complexes for polyketide assembly [19].

Dinoflagellates possess some of the largest genomes known from eukaryotes, from 1.85 to $112 \mathrm{Gbp}$ [20]. Their gene content has been estimated to be much smaller than would be anticipated based on their genome size, at $38,188-87,688$ protein coding genes [21]. The copy number of individual genes can vary significantly, between 30 copies (protein kinase gene in L. polyedrum) [22] to 5000 copies (peridinin-chlorophyll a-binding protein gene studied in L. polyedrum) [23], and up to 100,000 copies of common genes such as rRNA [24]. Such huge genome sizes and high gene copy numbers have made entire genome sequencing for these organisms unfeasible. Recent advancement of high throughput sequencing technologies has now made it feasible to study the gene content of these organisms at the genomic and transcriptomic level. Recently, a partial draft assembly of Symbiodinium minutum genome, which has amongst the smallest genomes of a dinoflagellate, has been achieved [25]. In dinoflagellates, the lack of axenic cultures, as well as the difficulty in constructing genetic mutations and screening mutants, has meant that confirming the roles of genes in biosynthetic pathways is currently not possible. Despite the challenges, type I modular PKS genes have been identified in Karenia brevis [26, 27], Heterocapsa circularisquama [28], Heterocapsa triquetra [29], Alexandrium ostenfeldii [29], Azadinium sp. [30] and several Amphidinium species [31, 32] via transcriptomics. In dinoflagellates mRNA undergoes trans-splicing with an addition of a 22-nt conserved spliced leader (SL) to the 5' end of the sequence [33]. Sequencing of full-length mature mRNA transcripts containing the SL sequence and phylogenetic analysis is necessary to distinguish these sequences from bacterial PKS genes, originating from non-axenic cultures. Interestingly, in most of the previous studies, full-length transcripts only encoded one catalytic domain, but were homologous to type I PKSs, suggesting a novel mono-functional type I PKS in dinoflagellates [29]. However, if polyether ladders are produced by modular type I PKS enzymes, based on the structure of these compounds, the PKS sequences discovered so far likely represent only a fraction of the PKS genes present.

Here we present comprehensive transcriptomic libraries of two species of gonyaulacaleaen and MTX producing dinoflagellates, Gambierdiscus australes and G. belizeanus. A large number of genes putatively involved in the biosynthesis of polyether ladder compounds were found. In addition, genes involved in other regulatory pathways were also mapped. Genome sizes and the number of genes were estimated using flow cytometry and statistical analysis. The toxin profiles of the species were generated via liquid chromatography- mass spectrometry (LC-MS) against toxin standards, and the toxicity was determined using mouse bioassay.

\section{Results and discussion}

\section{Genome size analysis}

We determined a DNA content of $33.2 \pm 3.8$ pg cell $^{-1}$ for Gambierdiscus australes and $35.8 \pm 0.9 \mathrm{pg} \mathrm{cell}^{-1}$ for G. belizeanus via flow cytometry (Supplemental data), which equates to a genome size of $32.5 \pm 3.7 \mathrm{Gbp}$ and $35 \pm 0.88$ Gbp, respectively (Fig. 2). While very large compared to other eukaryotes, both genomes were comparatively smaller than expected, given the large cell sizes of Gambierdiscus species based on a comparison of 23 dinoflagellate species (Additional file 1: Figure S1 and Table S1). Genome sequencing has been used to elucidate PKS gene clusters from many organisms, however, instead of sequencing such large genomes, comparative transcriptomic studies may be an efficient method for finding novel dinoflagellate genes [34, 35].

\section{Toxin analysis}

Cell extracts of G. australes CAWD149 contained MTX-1 and putative MTX-3, whereas G. belizeanus CCMP401 extract contained only putative MTX-3 (Fig. 2). No ciguatoxins were detected in extracts of either species. While the toxicity of MTX-1 to mice by IP injection is well documented [2], 


$$
\text { Premaitotoxin }
$$

Polyepoxidation

(1)

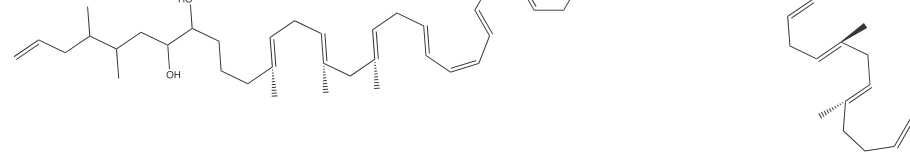

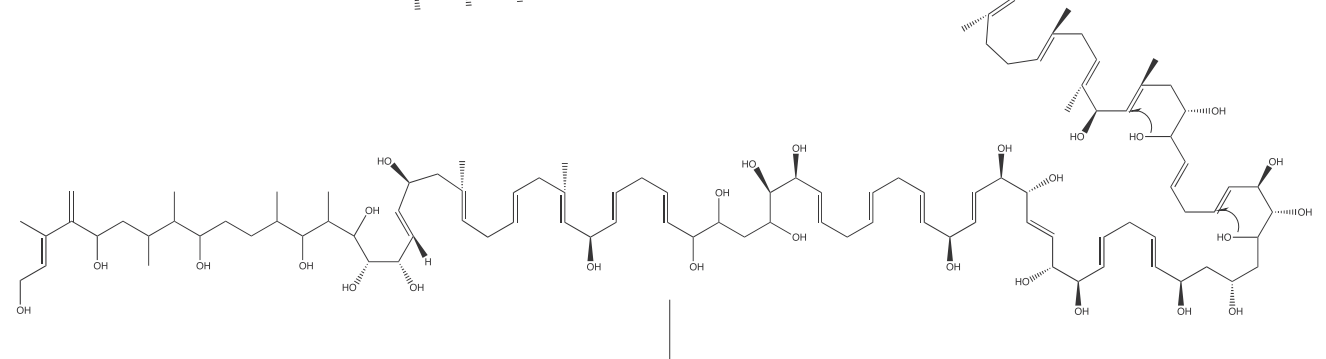

(1)
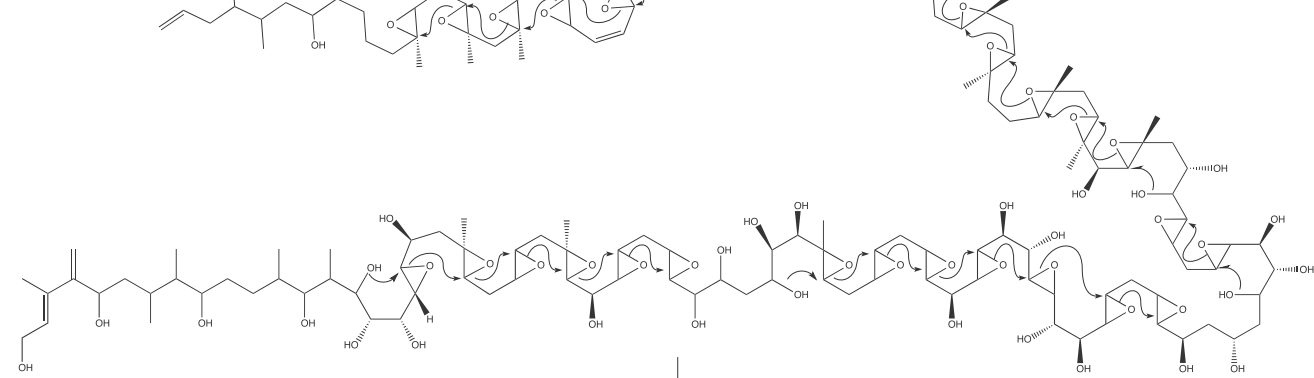

\section{Cyclisation \& sulfonation}
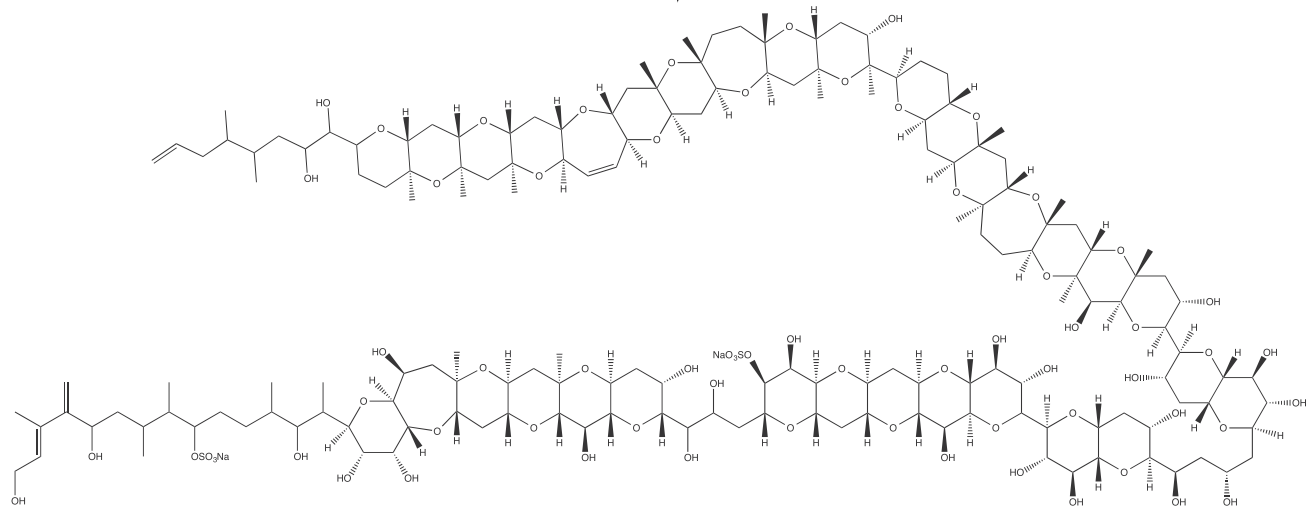

\section{Maitotoxin-1}

Fig. 1 Proposed mechanism for maitotoxin-1 production. Polyene (premaitotoxin) produced by polyketide biosynthesis undergoes epoxidation, epoxide cyclisation and sulfonation to form Maitotoxin-1 


\begin{tabular}{|c|c|c|c|c|}
\hline Organism & \multicolumn{2}{|l|}{ G. australes } & G. belizeanus & H) \\
\hline \multirow[t]{2}{*}{ LC-MS analysis } & 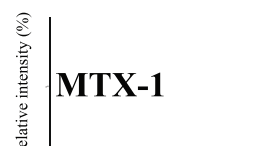 & $\begin{array}{l}\text { MRM of } 2 \text { channels ES } \\
16898.6>1698.6 \\
2.4805\end{array}$ & \multicolumn{2}{|c|}{ No MTX-1 detected } \\
\hline & MTX-3 & $\begin{array}{l}\text { MRM of } 2 \text { channels ES } \\
\text { 10.977.6 } \\
1.969 .8\end{array}$ & MTX-3 & 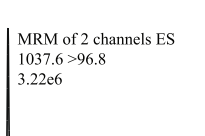 \\
\hline $\begin{array}{l}\text { Toxicity of crude extract via } \\
\text { mouse bioassay }\end{array}$ & $6.3 \mathrm{mg} \mathrm{kg}^{-1}$ & & $3.8 \mathrm{mg} \mathrm{k}$ & \\
\hline Genome size & $32.5 \pm 3.7 \mathrm{Gbp}$ & & $\mathbf{3 5} \pm \mathbf{0 . 8 8}$ & \\
\hline Expected number of genes & $\begin{array}{l}\text { Protein coding- } \\
\text { Total genes-65,5 }\end{array}$ & $\begin{array}{l}110 \pm 2627 \\
\pm 2772\end{array}$ & $\begin{array}{l}\text { Protein c } \\
\text { Total gen }\end{array}$ & $\begin{array}{l}976 \pm 580 \\
\pm 611\end{array}$ \\
\hline $\begin{array}{l}\text { Number of assembled contigs } \\
\text { via RNASeq >300bp (average length) }\end{array}$ & 83353 (1149) & & $84870(1$ & \\
\hline $\begin{array}{l}\text { Contigs with spliced leader sequence } \\
\text { (spliced leader and polyA) }\end{array}$ & 1373 (187) & & $1303(138$ & \\
\hline $\begin{array}{l}\text { CEGMA analysis } \\
\text { (ultra conserved) }\end{array}$ & $\begin{array}{l}386 \text { out of } 458 \\
\text { ( } 210 \text { out of } 248)\end{array}$ & & $\begin{array}{l}333 \text { out } \mathrm{a} \\
188 \text { out } \mathrm{c}\end{array}$ & \\
\hline $\begin{array}{l}\text { BLASTx analysis using } \\
\text { BLAST2GO } \\
\text { e-value cut-off } 10^{-3}\end{array}$ & $55 \%$ & & & \\
\hline & \begin{tabular}{|l} 
Annota \\
Non an \\
No mat
\end{tabular} & $\begin{array}{l}\text { match } \\
\text { ted match } \\
\text { n GenBank no }\end{array}$ & n-redundan & \\
\hline $\begin{array}{l}\text { PKS domains found in } \\
\text { transcriptome }\end{array}$ & $\begin{array}{l}\text { Ketosynthase-88 } \\
\text { Ketoreductase-8 } \\
\text { Acyltransferase- } \\
\text { Acyl carrier pro } \\
\text { Acyl carrier pro } \\
\text { Thioesterase-2 } \\
\text { Methyltransfera }\end{array}$ & $\begin{array}{l}\text { II), } 6 \text { (partial) } \\
\text { II), } 2 \text { (partial) } \\
-13 \\
\text { synthase-2 }\end{array}$ & $\begin{array}{l}\text { Ketosyntha } \\
\text { Ketoreduct: } \\
\text { Acyltransfe } \\
\text { Acyl carrieı } \\
\text { Acyl carrie } \\
\text { Thioesteras } \\
\text { Enoylreduc } \\
\text { Methyltran }\end{array}$ & $\begin{array}{l}\text { ), } 24 \text { (partial) } \\
\text { ), } 1 \text { (partial) } \\
14 \\
\text { ynthase-1 }\end{array}$ \\
\hline
\end{tabular}

Fig. 2 Genome sizes obtained via flow cytometry, chemical analyses via LC-MS, mouse bioassays and bioinformatic analysis of gene catalogues of $G$. australes and $G$. belizeanus

the toxicity of MTX-3 had not been previously determined. The cell extract of G. belizeanus had an $\mathrm{LD}_{50}$ of $3.8 \mathrm{mg} \mathrm{kg}^{-1}$ in mouse bioassays using IP injection, causing abdominal breathing, decreased respiration rates and ultimately death through respiratory paralysis. The $\mathrm{LD}_{50}$ of this extract is higher than that for pure MTX-1 $\left(0.05 \mu \mathrm{g} \mathrm{kg}{ }^{-1}\right)$ [2], but 
lower than the $\mathrm{LD}_{50}$ of other toxins such as saxitoxin $\left(8-10 \mu \mathrm{g} \mathrm{kg}^{-1}\right)[36,37]$. The structure of MTX-3 is not yet fully elucidated, however, it probably has a polyether ladder structure similar to MTX-1 [2].

\section{Transcriptomic analysis}

We generated comprehensive transcriptomic libraries of two species of MTX-producing and non-ciguatoxins (CTX) producing dinoflagellates, Gambierdiscus australes and G. belizeanus, with an aim to investigate the evolution of PKS enzyme complexes (for details, see experimental procedure in supplemental data). Here, we report gene catalogues of 83,353 (G. australes) and 84,870 (G. belizeanus) unique contigs, that are amongst the most comprehensive yet reported from dinoflagellates (Fig. 2). Based on the genome size, gene number was estimated as $62,110 \pm 2627$ protein-coding and $65,538 \pm 2772$ total genes per genome in G. australes, and $62,976 \pm 580$ protein-coding and 66,451 \pm 611 total genes per genome in $G$. belizeanus using the empirical regression equation of $\mathrm{Hou}$ \& Lin [21]. Sequences encoding all the essential enzymes involved in glycolysis, tricarboxalic acid cycle, C-3 carbon cycle, pentose phosphate pathway and oxidative phosphorylation were found and could be fully annotated among the 18,399 and 17,290 fully annotated sequences in G. australes and G. belizeanus transcriptomes respectively (Additional file 1: Table S2).

The presence of $84.27 \%$ (G. australes) and $72.7 \%$ (G. belizeanus) of 458 highly conserved proteins included in the core eukaryotic genes mapping approach (CEGMA) software, served as an additional test of the comprehensiveness of the catalogues (Fig. 2, [38]). The other published protist gene catalogues investigated via CEGMA analysis to date, Toxoplasma gondii, had $67.63 \%$ [38], Karenia brevis had $84 \%$ (SP1), $82 \%$ (SP3) and $81 \%$ (Wilson) [27] and Karlodinium micrum had 74 \% [39] of the 458 highly conserved protein datasets. However, some protein orthologues may not have been recognised using CEGMA analysis due to the high degree of sequence divergence of protists from other eukaryotes.

A full suite of histone encoding genes $(\mathrm{H} 2 \mathrm{~A}, \mathrm{H} 2 \mathrm{~B}, \mathrm{H} 3$, H4) was also found in both the gene catalogues (Additional file 1: Table S3) as previously reported in various Symbiodinium species [25, 40] and Lingulodinium polyedrum [41]. A phylogeny of the H2A histone proteins revealed the presence of H2A.X variants of the histone proteins. Dinoflagellate H2A.X sequences form a distinct well-supported clade and were clearly distinguished from other major groups of H2A.X and H2A.Z variants (Additional file 1: Figure S2).

In dinoflagellates, the presence of SL sequence provides a means to distinguish full-length mature dinoflagellate transcripts from transcripts derived from bacteria associated with non-axenic cultures. Our gene catalogue consisted of one of the largest collection of full-length transcripts (SL at 5 ' end and polyA tail at 3' end) reported for any dinoflagellate transcriptome library (Fig. 1, Additional file 1: Table S4). The fact that only $63 \%$ and $54 \%$ of full-length transcripts, respectively, could be annotated is intriguing, suggesting that many transcripts might be involved in novel processes. This was also the case for total transcripts in the gene catalogues, with more than $50 \%$ having no BLASTx match, similar to recently published catalogues from L. polyedrum (total of 74,655 contigs, $25 \%$ annotated matches, $45 \%$ nonannotated matches and $30 \%$ without similarity to any known sequences in GenBank [42]) and K.brevis (total of $43-45 \%$ of transcripts belonging to three strains had a positive BLASTp match to the nr database [27]).

Our Gambierdiscus gene catalogues contained a large number and diversity of genes putatively involved in polyketide biosynthesis, including a total of 162 unique transcripts (88 in G. australes and 74 in G. belizeanus) encoding complete KS domains (Fig. 2). The presence of dinoflagellate-specific SL in five KS transcripts, their similarity (BLASTx) to KS domains from other dinoflagellates (Additional file 1: Tables S5-S7) and the monophyletic clustering of all dinoflagellate KS transcripts within a protistan KS domain cluster in the phylogenies, provides consistent and substantial evidence of the dinoflagellate origin of these transcripts (Fig. 3a). The 185 dinoflagellate KS transcripts included in the phylogenetic analysis grouped with type I PKS with strong support and could be resolved in 5 well-supported clades within the dinoflagellate clade (Fig. 3a). As KS domains are used by PKSs and fatty acid synthases (FAS), the transcripts in these clades might be involved in either or both of these processes. The clades also consisted of KS transcripts found only in BTX-producing Karenia brevis [26, 27], including four KS transcripts found in both BTX-producing and non-producing $K$. brevis $[26,27]$, three KS transcripts from spirolide producing Alexandrium ostenfeldii [29], five KS transcripts from azaspiracid producing Azadinium spinosum [30], two KS transcripts from CTX producing G. polynesiensis [43], two KS transcripts from toxic Heterocapsa triquetra [29] and three KS transcripts from non-toxic H. circularisquama [28].

We suggest that clades $\mathrm{C}, \mathrm{D}$ and $\mathrm{E}$, which contain $\mathrm{KS}$ sequences from almost all dinoflagellates included in the analyses, are more likely to be involved in a common synthesis pathway, such as FAS. However, Clade A contained only KS sequences from polyether ladder-producing dinoflagellates while Clade B contained only KS sequences from G. belizeanus and G. australes (Fig. 3a), suggesting these sequences may be involved in the synthesis of MTXs or other unique PKS products from this genus. Most previous studies of KS diversity in dinoflagellate transcriptomes had much lower sequence depth and coverage, therefore similar sequences may be present in other species, but have not been detected. This includes the recently published $G$. 


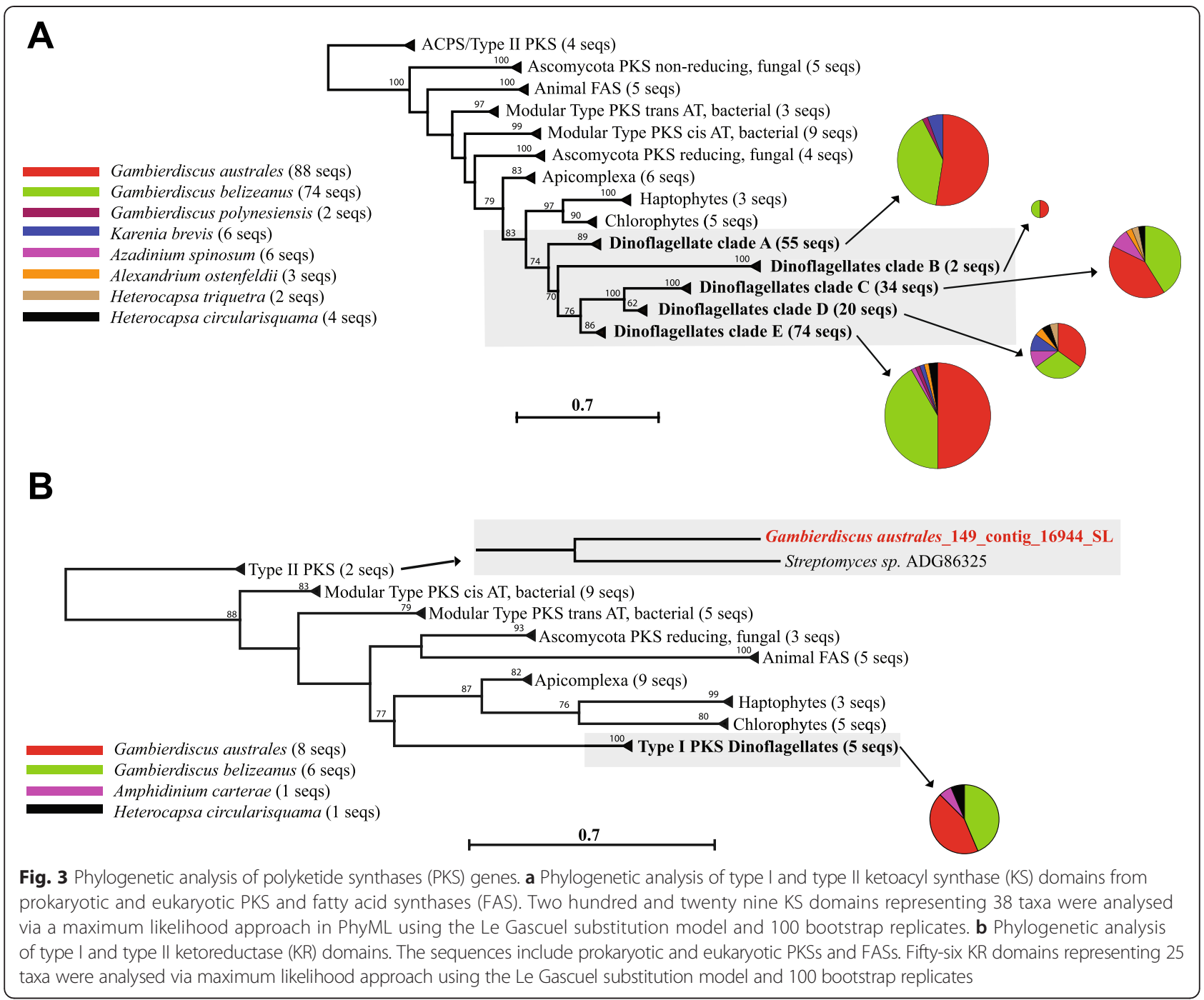

polynesiensis transcriptome [43] in which 33 transcripts encoding KS domains were detected, however, only two transcripts had full-length KS domains encoded. In-depth transcriptomic analysis of cultures of other dinoflagellates with comprehensive toxin profiles are required to be more certain of the role of the sequences in these three clades.

Both Gambierdiscus transcriptomes examined here also contained numerous other putative polyketide domains (Fig. 1, Additional file 1: Tables S8-S9), including a transcript resembling a type II KR domain (Fig. 3b, a $\mathrm{SL}$ at the start of the transcript confirms its dinoflagellate origin). KR domains have been found previously in K. brevis [26, 27], A. carterae [31] and A. spinosum [30]. This is the first study to show that the majority form a strongly supported cluster with type I PKS (Fig. 3b).

As demonstrated previously [26, 29, 43], a surprising feature of the dinoflagellate transcripts encoding KS and $\mathrm{KR}$ domains is that they contain only one domain per transcript. Previously this feature has been characteristic of type II PKSs, yet our phylogenetic analyses show that they formed strongly supported clades with other type I PKS sequences (Fig. 3), except for the single type II related KR domain described above (Fig. 3b). Other protists such as species of apicomplexans and haptophytes display classic type I PKS modules, containing several domains, encoded on a single transcript $[44,45]$ and it appears that the monofunctional expression of type I PKS transcripts is unique to dinoflagellates $[29,30]$.

Some PKS AT domain transcripts also encoded ankyrin proteins (Additional file 1: Table S9), which are known to mediate the attachment of integral membrane proteins in mammals [46]. ATs with ankyrin proteins are generally involved in many other pathways [47] and often are not embedded into PK megasynthases, but instead operating as individual trans proteins [48]. Their variable genomic clustering therefore makes it difficult to identify, which ATs may be involved in polyketide synthesis [49]. 
If MTX-1 is produced by type I modular PKS it would likely contain 69 modules, given the monofunctional role of these enzymes. If each KS domain in each module was encoded by a separate transcript then this accounts for the large number of transcripts recovered from these two Gambierdiscus species. Early theoretical pathways for polyether ladder synthesis predict epoxidation and cyclisation of polyether ladders during polyketide synthesis [50], however, the pathway proposed here involves modification of the carbon backbone after polyketide synthesis (Fig. 1) as in the case of monensin biosynthesis, which is a non-ladder polyether compound [10,12]. We also detected transcripts encoding for enzymes epoxidases, epoxy hydrolases and sulfotransferases that could perform expoxidation, cyclisation and sulfonation of polyether compounds, respectively (Additional file 1: Table S10), supporting the proposed biosynthesis.

\section{Conclusion}

In dinoflagellates, the difficulty of generating and subsequent poor survival of axenic cultures, combined with the difficulty of genetic transformation and screening, means that confirming the role of genes in toxin biosynthesis pathways is currently very difficult. Linking genes to polyketide production in dinoflagellates requires comparative transcriptomic studies of species with contrasting polyketide production profiles. The results presented here are a major contribution towards eventually recognising the genes that encode a critical step in each type of polyketide biosynthesis.

\section{Methods}

\section{Gambierdiscus cell culture}

Gambierdiscus australes (CAWD149, originally isolated from Cook Islands, Pacific Ocean, kindly provided by Lesley Rhodes, Cawthron Institutes culture collection of Micro Algae) and Gambierdiscus belizeanus (CCMP401, originally isolated from Barthelemy Island, Caribbean Sea, North Atlantic Ocean, purchased from National Centre for Marine Algae and Microbiota) strains were cultured at $25{ }^{\circ} \mathrm{C}$ under cool white fluorescent light at a light intensity of $60 \mu \mathrm{mol} \mathrm{m} \mathrm{m}^{-2} \mathrm{~s}^{-1}$ and a 12:12 light:dark cycle. G. australes was grown in $\mathrm{f} / 2$ medium [51] $G$. belizeanus was grown in K medium [52].

\section{DNA and RNA extraction}

For DNA and RNA extraction of G. australes, cells were harvested by separation over $3.0 \mu \mathrm{M}$ filters (Merck Millipore, Darmstadt, Germany) and washed with Phosphate buffered saline (Sigma, St. Louis, MO) three times to minimise bacterial contamination.

For, DNA extraction the cell pellet was extracted via FastDNA $^{\bullet}$ Spin kit for Soil (MP Biomedicals, Solon, $\mathrm{OH})$. The manufacturer's protocol was followed, and samples were stored at $-20{ }^{\circ} \mathrm{C}$ until further analysis.
For, RNA extraction the cell pellet was first extracted via TriReagent ${ }^{\circ}$ (Life Technologies, Carlsbad, CA) using the manufacturer's protocol. The obtained RNA was purified using the RNeasy Plant mini kit (Qiagen, Limberg, Netherlands) according to the manufactures protocol. Any residual DNA was removed via the TURBO DNA-free ${ }^{\mathrm{rm}}$ Kit (Life Technologies) and RNA was stored at $-80^{\circ} \mathrm{C}$ until further analysis. The RNA purity, quantity and integrity were assessed using Nanodrop ND-1000 (Thermo Scientific, Woltham, MA) and 2100 Bioanalyser (Agilent Technologies, Santa Clara, CA).

\section{Toxin analysis via LC-MS and mouse bioassay}

G. australes and G. belizeanus cell pellets were extracted using a previously standardised method for CTX [53] and MTX analysis [54]. The LC-MS analysis was performed at the Cawthron Institute, Nelson, New Zealand, with multiple-reaction monitoring for CTX-3b, CTX-3C, CTX-4A, CTX-4B, MTX-1 and MTX-3.

Mouse bioassays were conducted at Agri Research, Hamilton, New Zealand. To test the toxicity of MTX-3, a cell pellet of $G$. belizeanus containing $4.776 \times 10^{6}$ cells extracted with methanol. The dried extract was dissolved in $1 \%$ Tween 60 in saline and female Swiss albino mice (body weight 18-22 g) were injected intra-peritoneally with this solution at various dose levels. The $\mathrm{LD}_{50}$ values were determined by the up-and-down method [55].

\section{Genome size estimation via flow cytometry}

Synchronisation and sample collection was achieved by inoculating G. australes and G. belizeanus cell cultures at an initial concentration of 1000 cells $\mathrm{ml}^{-1}$. The cells were grown for eight days and then synchronised via 48:48:48 $\mathrm{h}$ dark:light:dark cycle and then harvested via centrifugation at $1000 \mathrm{~g}$ for $5 \mathrm{~min}$. The cell pellet was resuspended in $4 \mathrm{~mL}$ of methanol and stored until further analysis. For, flow cytometry, the collected cells were washed twice in PBS and the pellet was resuspended in a staining solution (PBS, $100 \mu \mathrm{g}$ propidium iodide $\mathrm{mL}^{-1}$ and $2 \mu \mathrm{g}$ RNaseA. $\mathrm{mL}^{-1}$ ) for at least $4 \mathrm{~h}$ before analysis. A Beckman FC500 bench flow cytometer (Beckman Coulter, Brea, CA) with a laser emitting at $488 \mathrm{~nm}$ was used. Three replicate samples for each species were run at low speed and data were acquired in linear and log modes until at least 1000 events had been recorded. As DNA standard, $10 \mu$ of a triploid trout solution (7.8 pg/nucleus, Biosure, Grass valley, CA) was added to each sample. Fluorescence emission of propidium iodide was detected at $620 \mathrm{~nm}$. FlowJo 7.6 (Tree Star Inc., Ashland, OR) was used to compute peak numbers, coefficients of variation (CVs), and peak ratios for the DNA fluorescence distributions in a population. $\mathrm{CV}$ values were typically less than $20 \%$. The genome size was calculated based on the conversion factor $1 \mathrm{pg}=978 \mathrm{Mbp}$ [56]. 
To make valid predictions of gene numbers in the genome, the empirical regression equation $y^{\prime}=\ln \left(-46.200+22.217 x^{\prime}\right)$ and $y^{\prime}=\ln \left(247.28+22.74 x^{\prime}\right)$ provided by Hou \& Lin [21] were used to calculate the predicted protein coding genes and total number of genes in a genome, respectively. In the equation $y^{\prime}=\log _{10}$ gene number and $x^{\prime}=\log _{10}$ genome size in $\mathrm{kbp}$.

\section{Transcriptome analysis}

RNA extracted from G. australes CAWD149 and G. belizeanus CCMP401 was sequenced using a HiSeq2000 (Illumina, San Diego, CA) generating 100 bp paired-end reads. The libraries were prepared using the TruSeq ${ }^{\text {тM }}$ RNA Sample Prep Kit v2 following the manufacturer's description (Illumina, order no. RS-122-200x) which involves selective polyA ${ }^{+}$RNA enrichment using magnetic beads followed by fragmentation of enriched RNA fraction (for only 4 min to obtain also fragments with sizes $>300 \mathrm{bp}$ ), adapter ligation and amplification. For sequencing both libraries were multiplexed in one lane. A total of 79,265,976 and 61,587,248 read pairs were extracted in FastQ format using CASAVA v1.8.2 (Illumina) for G. australes and G. belizaeanus, respectively. Raw reads were quality filtered and assembled into contigs using the CLC Genomics Workbench (CLC bio, Cambridge, MA) and the software's default settings. Any contigs with a length of less than $300 \mathrm{bp}$ (based on the length of the insert size) were not analysed further. BLASTx analysis, mapping, annotation and Kyoto Encyclopedia of Gene and Genomes (KEGG) analysis for both the gene catalogues was performed using BLAST2GO [57]. BLASTx was performed against the $\mathrm{nr}$ database of GenBank and an E-value cut off of $10^{-3}$ was used. For mapping and annotations, the default values of BLAST2GO were used. To analyse the comprehensiveness of the gene catalogues the Core Eukaryotic Genes Mapping approach (CEGMA) tool was used [38]. Identification of potential genes involved in polyketide biosynthesis was achieved by text searching the annotations (ketosynthase, PKS, polyketide synthase, ketoreductases). For the identification of KS and KR domains, these sequences were further analysed by PKS-NRPS analysis software [58] and HMMER [59] (using an in-house developed HMM databases). Functional prediction of sequences was also aided by running Pfam [60] searches. To calculate the amount of sequences of bacterial origin, any sequences with a top BLASTx hit to prokaryotic organisms were counted.

For phylogenetic analysis, all steps were performed in Geneious $^{\circ}$ software [61]. Sequences from different datasets were aligned using MAFFT v6.814b [62]. Alignments were trimmed manually to ensure they spanned the same $\mathrm{KS} / \mathrm{KR} /$ Histone2a coding region. After aligning the sequences, the best substitution model was determined using ModelTest [39] and a maximum likelihood phylogenetic analysis was carried out using the program PhyML [63] with 100 bootstraps.

\section{Additional file}

\begin{abstract}
Additional file 1: Figure S1. Correlation between cell dimensions (length of dorso-ventral axis of a cell) and quantity of nuclear DNA in 27 different species of dinoflagellates (23 genera). Figure S2. Phylogenetic analysis of $\mathrm{H} 2 \mathrm{~A}$ histone proteins. Table $\mathrm{S1}$. Data used to estimate the correlation between cell dimensions and quantity of nuclear DNA in dinoflagellates (23 genera). Table S2. Description of different sequences from G. australes and $G$. belizeanus encoding essential enzymes for Glycolysis, TCA cycle, Oxidative phosphorylation, Carbon fixation (c3) cycle and pentose phosphate pathway. Table S3. A list of all the sequencing encoding the histone proteins found in the gene catalogue of $G$. australes and $G$. belizeanus. Table S4. A list of sequences from $G$. australes and $G$. belizeanus gene catalogue containing spliced leader at the $5^{\prime}$ end and polyA tail at the $3^{\prime}$ end. Table S5. Sequence properties of the transcripts encoding full ketoacyl synthase domain identified in G. australes CAWD149. Table S6. Sequence properties of the transcripts encoding full ketoacyl synthase domain identified in G. belizeanus. Table S7. Sequence properties of the transcripts encoding partial ketoacyl synthase domain identified in G. australes and G. belizeanus. Table S8. Sequence properties of the transcripts encoding full and partial ketoyl reductase domains identified in G. australes and G. belizeanus. Table S9. Sequence properties of the transcripts encoding full acyl carrier protein synthase, enoylreductase, acyltransferase, acyltransferase with ankyrin adaptor proteins, acyl carrier protein domains identified in G. australes and G. belizeanus. Table 10. Sequence properties of the transcripts encoding epoxidases, epoxide hydrolases and full and partial sulfotransferases enzymes identified in G. australes and G. belizeanus. Table S11. Sequence properties of the transcripts encoding full acyl carrier protein synthase, Enoyl reductase, acyl transferase, acyl carrier protein identified in G. australes and G. belizeanus. Table S12. Sequence properties of the transcripts encoding epoxide hydrolases and sulfotransferases enzymes identified in G. australes and G. belizeanus. Table S13. Sequence properties of the transcripts encoding multiple Type I PKS domains identified in G. australes and G. belizeanus.
\end{abstract}

\section{Abbreviations}

(OA): Okadaic acid; (BTXs): Brevetoxins; (MTXs): Maitotoxins;

(DTXs): Dinophysistoxins; (PKS): Polyketide synthases; (AT): Acyltransferase domain; (KS): $\beta$-ketosynthase domain; (ACP): Acyl carrier protein; (KR): $\beta$-ketoacyl reductase; (ER): Enoyl reductase; (MT): Methyl transferases; (TE): Thioesterases;

(DH): Dehydrogenase; (FAS): Fatty acid synthesis; (SL): Spliced leader; (LC-MS): Liquid chromatography- mass spectrometry; (CEGMA): Core eukaryotic genes mapping approach and ciguatoxins (CTX).

\section{Competing interests}

The authors declare that they have no competing interests.

\section{Author's contributions}

Conception and design of the research was by SM, GK and CB. Cultures were provided by LR and CB. Gathering of data, determination, analysis and interpretation of research data was conducted by GK, SM, UJ, MG, RF, LR and $\mathrm{TH}$. The manuscript was written by SM and GK with some input from CB. All authors read and approved the final manuscript.

\section{Acknowledgements}

Funding for this project was provided by an Australian Research Council grant to SM (FT120100704), the Safe New Zealand Seafood programme, Formas (Sweden), and the PACES research program of the Alfred Wegener Institute for Polar and Marine Research. GK was partly funded by an Australian Postgraduate Award from University of New South Wales (Australia). CB was funded by an Australian Research Council Discovery grant (DP0880264). Transcriptomic sequencing was carried out at the Leibniz-Institute for Age Research, Fritz Lipmann Institute Jena, Germany. We thank Dr. Rex Munday of AgResearch (Hamilton, New Zealand) for performing the mouse bioassays and Prof. Naresh Kumar of the University of New South Wales (Australia) for help with the proposed biosynthesis of MTX-1. We thank Prof. Brett A. Neilan of University of New South Wales (Australia) for initial discussions and proof reading the manuscript. 


\section{Author details}

${ }^{1}$ Plant Functional Biology and Climate Change Cluster, University of Technology Sydney, Broadway, New South Wales 2007, Australia. ${ }^{2}$ School of Biotechnology and Biomolecular Sciences, University of New South Wales, Kensington, New South Wales 2052, Australia. ${ }^{3}$ Alfred Wegener Institute for Polar and Marine Research, Bremerhaven 27515, Germany. ${ }^{4}$ Aquatic Ecology, Department of Biology, Lund University, Lund 223 62, Sweden. ${ }^{5}$ Cawthron Institute, Nelson 7010, New Zealand. ${ }^{6}$ Leibniz Institute for Age Research, Fritz Lipmann Institute, Jena D-07745, Germany. ' Institute for Marine and Antarctic Studies, University of Tasmania, Launceston 7248, Tasmania, Australia. ${ }^{8}$ Sydney Institute of Marine Sciences, Mosman, New South Wales 2088, Australia.

\section{Received: 6 October 2014 Accepted: 7 May 2015}

\section{Published online: 28 May 2015}

\section{References}

1. Murata M, Naoki H, Iwashita T, Matsunaga S, Sasaki M, Yokoyama A, et al. Structure of maitotoxin. J Am Chem Soc. 1993;115:2060-2.

2. Holmes MJ, Lewis RJ. Purification and characterisation of large and small maitotoxins from cultured Gambierdiscus toxicus. Nat Toxins. 1994;2:64-72.

3. Kalaitzis JA, Chau R, Kohli GS, Murray SA, Neilan BA. Biosynthesis of toxic naturally-occurring seafood contaminants. Toxicon. 2010;56:244-58.

4. Kellmann R, Stüken A, Orr RJ, Svendsen HM, Jakobsen KS. Biosynthesis and molecular genetics of polyketides in marine dinoflagellates. Mar Drugs. 2010;8:1011-48.

5. Lee MS, Repeta DJ, Nakanishi K, Zagorski MG. Biosynthetic origins and assignments of carbon 13 NMR peaks of brevetoxin B. J Am Chem Soc. 1986;108:7855-6.

6. Chou HN, Shimizu Y. Biosynthesis of brevetoxins. Evidence for the mixed origin of the backbone carbon chain and possible involvement of dicarboxylic acids. J Am Chem Soc. 1987;109:2184-5.

7. Lee MS, Qin G, Nakanishi K, Zagorski MG. Biosynthetic studies of brevetoxins, potent neurotoxins produced by the dinoflagellate Gymnodinium breve. J Am Chem Soc. 1989;111:6234-41.

8. Wright JLC, Hu T, McLachlan JL, Needham J, Walter JA. Biosynthesis of DTX-4: Confirmation of a Polyketide Pathway, Proof of a Baeyer - Villiger Oxidation Step, and Evidence for an Unusual Carbon Deletion Process. J Am Chem Soc. 1996;118:8757-8.

9. Murata M, Izumikawa M, Tachibana K, Fujita T, Naoki H. Labeling pattern of Okadaic acid from 1802 and acetate elucidated by collision-induced dissociation tandem mass spectrometry. J Am Chem Soc. 1998;120:147-51.

10. Leadlay PF, Staunton J, Oliynyk M, Bisang C, Cortes J, Frost E, et al. Engineering of complex polyketide biosynthesis-insights from sequencing of the monensin biosynthetic gene cluster. J Ind Microbiol Biotechnol. 2001:27:360-7.

11. Sun Y, Zhou X, Dong H, Tu G, Wang M, Wang B, et al. A Complete Gene Cluster from Streptomyces nanchangensis NS3226 Encoding Biosynthesis of the Polyether lonophore Nanchangmycin. Chem Biol. 2003;10:431-41.

12. Oliynyk M, Stark CBW, Bhatt A, Jones MA, Hughes-Thomas ZA, Wilkinson C, et al. Analysis of the biosynthetic gene cluster for the polyether antibiotic monensin in Streptomyces cinnamonensis and evidence for the role of monB and monC genes in oxidative cyclization. Mol Microbiol. 2003;49:1179-90

13. Minami A, Ose T, Sato K, Oikawa A, Kuroki K, Maenaka K, et al. Allosteric Regulation of Epoxide Opening Cascades by a Pair of Epoxide Hydrolases in Monensin Biosynthesis. ACS Chem Biol. 2014:9:562-9.

14. Rein KS, Snyder RV. The biosynthesis of polyketide metabolites by dinoflagellates. Adv Appl Microbiol. 2006:59:93-125.

15. Yamazaki M, Izumikawa M, Tachibana K, Satake M, Itoh Y, Hashimoto M. Origins of Oxygen Atoms in a Marine Ladder-Frame Polyether: Evidence of Monooxygenation by 180-Labeling and Using Tandem Mass Spectrometry. J Org Chem. 2012;77:4902-6.

16. Khosla C, Gokhale RS, Jacobsen JR, Cane DE. Tolerance and specificity of polyketide synthases. Annu Rev Biochem. 1999;68:219-53.

17. Smith S. The animal fatty acid synthase: one gene, one polypeptide, seven enzymes. FASEB J. 1994:8:1248-59.

18. Smith S, Witkowski A, Joshi AK. Structural and functional organization of the animal fatty acid synthase. Prog Lipid Res. 2003;42:289-317.

19. Rawlings BJ. Biosynthesis of polyketides (other than actinomycete macrolides). Nat Prod Rep. 1999;16:425-84.
20. LaJeunesse TC, Lambert G, Andersen RA, Coffroth MA, Galbraith DW. Symbiodinium (Pyrrhophyta) genome sizes (DNA content) are smallest among dinoflagellates. J Phycol. 2005;41:880-6.

21. Hou Y, Lin S. Distinct gene number-genome size relationships for eukaryotes and non-eukaryotes: gene content estimation for dinoflagellate genomes. PLoS One. 2009;4:e6978.

22. Salois $P$, Morse $D$. Charecterisation and molecular phylogeny of a protein kinase cDNA from the dinoflagellate Gonyaulax (Dinophyceae). J Phycol. 1997;33:1063-72

23. Le QH, Markovic P, Hastings JW, Jovine RVM, Morse D. Structure and organization of the peridinin-chlorophyll a-binding protein gene in Gonyaulax polyedra. Mol Gen Genet MGG. 1997;255:595-604.

24. Murray SA, Wiese M, Stüken A, Brett S, Kellmann R, Hallegraeff G, et al. sxtA-based quantitative molecular assay to identify saxitoxin-producing harmful algal blooms in marine waters. Appl Environ Microbiol. 2011;77:7050-7.

25. Shoguchi E, Shinzato C, Kawashima T, Gyoja F, Mungpakdee S, Koyanagi $R$, et al. Draft Assembly of the Symbiodinium minutum Nuclear Genome Reveals Dinoflagellate Gene Structure. Curr Biol. 2013;23:1399-408.

26. Monroe EA, Van Dolah FM. The toxic dinoflagellate Karenia brevis encodes novel type I-like polyketide synthases containing discrete catalytic domains. Protist. 2008;159:471-82.

27. Ryan D, Pepper A, Campbell L. De novo assembly and characterization of the transcriptome of the toxic dinoflagellate Karenia brevis. BMC Genomics. 2014;15:888.

28. Salcedo T, Upadhyay RJ, Nagasaki K, Bhattacharya D. Dozens of toxin-related genes are expressed in a nontoxic strain of the dinoflagellate Heterocapsa circularisquama. Mol Biol Evol. 2012;29:1503-6.

29. Eichholz K, Beszteri B, John U. Putative monofunctional type I polyketide synthase units: a dinoflagellate-specific feature? PLoS One. 2012;7:e48624

30. Meyer JM, Rödelsperger C, Eichholz K, Tillmann U, Cembella A, McGaughran A, et al. Transcriptomic characterisation and genomic glimps into the toxigenic dinoflagellate Azadinium spinosum, with emphasis on polykeitde synthase genes. BMC Genomics. 2015;16:27.

31. Bachvaroff TR, Place AR. From stop to start: tandem gene arrangement, copy number and trans splicing sites in the Dinoflagellate Amphidinium carterae. PLoS One. 2008;3, e2929.

32. Murray SA, Garby T, Hoppenrath M, Neilan BA. Genetic Diversity, Morphological Uniformity and Polyketide Production in Dinoflagellates (Amphidinium, Dinoflagellata). PLoS One. 2012;7, e38253.

33. Zhang H, Hou Y, Miranda L, Campbell DA, Sturm NR, Gaasterland T, et al. Spliced leader RNA trans-splicing in dinoflagellates. Proc Natl Acad Sci U S A. 2007;104:4618-23.

34. Jaeckisch N, Yang I, Wohlrab S, Glöckner G, Kroymann J, Vogel H, et al. Comparative genomic and transcriptomic characterization of the toxigenic marine dinoflagellate Alexandrium ostenfeldii. PLoS One. 2011;6, e28012.

35. Murray SA, Patterson DJ, Thesson A. Transcriptomics and microbial eukaryotic diversity: a way forward. Trends Ecology and Evol. 2012;27:651-2.

36. Oshima Y. Postcolumn derivatization liquid chromatographic method for paralytic shellfish toxins. J AOAC Int. 1995;78:528-32.

37. Harwood DT, Boundy M, Selwood Al, van Ginkel R, MacKenzie L, McNabb PS. Refinement and implementation of the Lawrence method (AOAC 2005.06) in a commercial laboratory: Assay performance during an Alexandrium catenella bloom event. Harmful Algae. 2013;24:20-31.

38. Parra G, Bradnam K, Korf I. CEGMA: a pipeline to accurately annotate core genes in eukaryotic genomes. Bioinformatics. 2007;23:1061-7.

39. Posada D, Crandall KA. MODELTEST: testing the model of DNA substitution Bioinformatics. 1998;14:817-8

40. Bayer T, Aranda M, Sunagawa S, Yum LK, DeSalvo MK, Lindquist E, et al. Symbiodinium transcriptomes: genome insights into the dinoflagellate symbionts of reef-building corals. PLoS One. 2012;7:e35269.

41. Roy S, Morse D. A Full Suite of Histone and Histone Modifying Genes Are Transcribed in the Dinoflagellate Lingulodinium. PLoS One. 2012;7:e34340

42. Beauchemin M, Roy S, Daoust P, Dagenais-Bellefeuille S, Bertomeu T, Letourneau $L$, et al. Dinoflagellate tandem array gene transcripts are highly conserved and not polycistronic. Proc Natl Acad Sci U S A. 2012;109:15793-8.

43. Pawlowiez R, Morey JS, Darius HT, Chinain M, Van Dolah FM. Transcriptome sequencing reveals single domain Type I-like polyketide synthases in the toxic dinoflagellate Gambierdiscus polynesiensis. Harmful Algae. 2014;36:29-37. 
44. Zhu G, LaGier MJ, Stejskal F, Millership JJ, Cai X, Keithly JS. Cryptosporidium parvum: the first protist known to encode a putative polyketide synthase. Gene. 2002;298:79-89.

45. John U, Beszteri B, Derelle E, Van de Peer Y, Read B, Moreau H, et al. Novel insights into evolution of protistan polyketide synthases through phylogenomic analysis. Protist. 2008;159:21-30.

46. Bennett V, Baines AJ. Spectrin and ankyrin-based pathways: metazoan inventions for integrating cells into tissues. Physiol Rev. 2001;81:1353-92.

47. Hemsley PA, Grierson CS. The ankyrin repeats and DHHC S-acyl transferase domain of AKR1 act independently to regulate switching from vegetative to mating states in yeast. PLoS One. 2011;6, e28799.

48. Musiol EM, Weber T. Discrete acyltransferases involved in polyketide biosynthesis. Med Chem Commun. 2012;3:871-86.

49. Cheng $Y-Q$, Tang G-L, Shen B. Type I polyketide synthase requiring a discrete acyltransferase for polyketide biosynthesis. Proc Natl Acad Sci U S A. 2003;100:3149-54.

50. Shimizu Y. Microalgal metabolites. Curr Opin Microbiol. 2003:6:236-43.

51. Guillard RRL, Ryther JH. Studies of marine planktonic diatoms: I. Cyclotella nana hustedt, and Detonula confervacea (cleve) gran. Can J Microbiol. 1962;8:229-39.

52. Keller MD, Selvin RC, Claus W, Guillard RRL. Media for the culture of oceanic untraphytoplankton. J Phycol. 1987;23:633-8.

53. Rhodes LL, Smith KF, Munday R, Selwood Al, McNabb PS, Holland PT, et al. Toxic dinoflagellates (Dinophyceae) from Rarotonga, Cook Islands. Toxicon. 2010;56:751-8

54. Kohli GS, Papiol GG, Rhodes LL, Harwood DT, Selwood A, Jerrett A, et al. A feeding study to probe the uptake of Maitotoxin by snapper (Pagrus auratus). Harmful Algae. 2014;37:125-32.

55. OECD. OECD Guideline for Testing of Chemicals 425. Acute Oral Toxicity - Upand Down-Procedure (UDP). Organisation for Economic Co-operation and Development. Paris: Organisation for Economic Co-operation and Development; 2006.

56. Doležel J, Bartoš J, Voglmayr H, Greilhuber J. Nuclean DNA content and Genome Size of Trout and Human. Cytometry A. 2003;51A:127-8.

57. Götz S, García-Gómez JM, Terol J, Williams TD, Nagaraj SH, Nueda MJ, et al. High-throughput functional annotation and data mining with the Blast2GO suite. Nucleic Acids Res. 2008:36:3420-35.

58. Bachmann BO, Ravel J. Chapter 8 Methods for In Silico Prediction of Microbial Polyketide and Nonribosomal Peptide Biosynthetic Pathways from DNA Sequence Data. In Methods Enzymol., Volume Volume 458, A.H. David, ed. (Academic Press), New York; 2009. p. 181-217.

59. Finn RD, Clements J, Eddy SR. HMMER web server: interactive sequence similarity searching. Nucleic Acids Res. 2011;39:W29-37.

60. Punta M, Coggill PC, Eberhardt RY, Mistry J, Tate J, Boursnell C, et al. The Pfam protein families database. Nucleic Acids Res. 2012;40:D290-301.

61. Kearse M, Moir R, Wilson A, Stones-Havas S, Cheung M, Sturrock S, et al. Geneious Basic: An integrated and extendable desktop software platform for the organization and analysis of sequence data. Bioinformatics. 2012;28:1647-9.

62. Katoh K, Misawa K, Kuma Kl, Miyata T. MAFFT: a novel method for rapid multiple sequence alignment based on fast Fourier transform. Nucleic Acids Res. 2002;30:3059-66.

63. Guindon S, Dufayard J-F, Lefort V, Anisimova M, Hordijk W, Gascuel O. New Algorithms and Methods to Estimate Maximum-Likelihood Phylogenies: Assessing the Performance of PhyML 3.0. Syst Biol. 2010;59:307-21.

\section{Submit your next manuscript to BioMed Central and take full advantage of:}

- Convenient online submission

- Thorough peer review

- No space constraints or color figure charges

- Immediate publication on acceptance

- Inclusion in PubMed, CAS, Scopus and Google Scholar

- Research which is freely available for redistribution 